\title{
Variability of Body Morphometric Parameters of Dwarf Sheep of Djallonke Breed according to the Ecotype (North and South), Age and Type of Birth
}

Adjibode G., Tougan U. P., Daouda I. H., Zannou M. S., Hanzen C. and Koutinhouin G. B.

J Anim Pro Adv 2016, 6(10): 999-1007

DOI: $10.5455 /$ japa.19691231040001

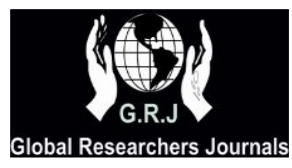


Original Article

\title{
Variability of Body Morphometric Parameters of
}

\section{Dwarf Sheep of Djallonke Breed according to the}

\section{Ecotype (North and South), Age and Type of Birth}

\author{
${ }^{1}$ Adjibode G., ${ }^{* 1,2}$ Tougan U. P., ${ }^{2}$ Daouda I. H., ${ }^{1,3}$ Zannou M. S., ${ }^{4}$ Hanzen C. and \\ ${ }^{1}$ Koutinhouin G. B.
}

\begin{abstract}
${ }^{1}$ Research Unit of Animal Husbandry and Meat Products Quality Control of Animal Production and Health Department, Polytechnic School of Abomey-Calavi, 01 BP 2009, Cotonou, Republic of Benin, Benin.

${ }^{2}$ National Agro-Pastoral High School of Parakou (ENSAP-Parakou), University of Parakou, Republic of Benin.

${ }^{3}$ Regional Excellence Centre of Avian Sciences of the University of Lome, BP 1515, Lome, Republic of Togo.

${ }^{4}$ Service de Thériogénologie, Département clinique des animaux de production, Faculté de Médecine Vétérinaire, Université de Liège.
\end{abstract}

\begin{abstract}
The study aims to determine morphometric parameters of North and South ecotypes of Djallonke sheep of Benin by age and type of birth. Data were collected from November 2013 to December 2015 on 462 sheeps of North ecotype and 599 of South ecotype. These data were analyzed with SAS software (2006). It appears that all morphometric traits depend on the ecotype of sheep except body length. Indeed, the sheep of North ecotype were heavier $(\mathrm{P}<0.001)$ than south ecotype sheep and had recorded the greater wither's height $(\mathrm{P}<0.001)$ with the higher values of head length, shoulders width, hip length, tail length and cannon perimeter. Similarly, chest perimeter of sheep of North ecotype was $59.64 \mathrm{~cm}$ to $57.9 \mathrm{~cm}$ for South ecotype $(\mathrm{P}<0.05)$. The values of live weight, head length, body length, hip length, tail length and height at wither increased very significantly with the age of animals $(\mathrm{P}<0.001)$. The single born lambs weighed heavier than lambs born from twin, triple and quadruple litter size, and had the highest body length, shoulder width and wither's height $(\mathrm{P}<0.01)$. As for correlations, from the cannon perimeter which is slightly and positively associated with live weight $(\mathrm{r}=0.12 ; \mathrm{P}<0.05)$, weakly and positively associated with head length $(\mathrm{r}=0.16 ; \mathrm{P}<0.01)$, the other measured morphometric parameters were strongly and positively associated with live weight $(0.30 \leq \mathrm{r} \leq 0.85 ; \mathrm{P}<0.001)$ and head length $(0.26 \leq \mathrm{r} \leq 0.81$; $\mathrm{P}<0.001)$. Therefore, selection based on one trait will improve the other traits as a correlated response.
\end{abstract}

\footnotetext{
Keywords: Benin, ecotype, Djallonke sheep, morphometric traits, variation.
}

\footnotetext{
* Corresponding author: Research Unit of Animal Husbandry and Meat Products Quality Control of Animal Production and Health Department, Polytechnic School of Abomey-Calavi, 01 BP 2009, Cotonou, Republic of Benin, Benin.

Received on: 15 Oct 2016

Revised on: 25 Oct 2016

Accepted on: 28 Oct 2016

Online Published on: 30 Oct 2016
} 


\section{Introduction}

The small ruminant production in general and sheep rearing in particular is a widthspread activity in most countries in sub-Saharan Africa (Gbangboché et al., 2005a, SWAC-OECD/ ECOWAS 2008; Babatunde et al., 2010). According to Fournier (2006), the sheep is a herbivore ruminant belonging to the Animalia kingdom, Chordata phylum, Vertibrata sub-phylum, Mammalia class, Ungulata order, Artiodactyla sub-order, Bovidae family, Caprinae sub-family, Ovis genus and aries species. The sheep Djallonke native from Fouta Djallon has today spread over the south area of the $14^{\text {th }}$ parallel of West Africa and Central Africa. It is found in Mali, Senegal, Guinea, Benin, Nigeria, Ghana, Togo, Niger, Cameroon, Ivory Coast, Central African Republic, Burkina Faso and Tchad.

West African Dwarf sheep production plays a very vital role in the livelihood of rural populations in sub-Saharan Africa as sales of the animals and their products help to stabilize household income. The tropical environment, with its characteristic harsh weather conditions, adversely affect meat and reproductive performance of animals (El-Hassan et al., 2009).

However, according to Gbangboché et al., (2005b), Youssao et al., (2008) and Adjibode et al., (2016), the reproductive performances of Djallonke sheep in Benin is weak, amongst others, due to a low fertility rate in the breeding herds. There is therefore a need for sustainable improvement strategies to keep up with the increasing demand of meat production and the productivity of sheep. These improvement strategies of sheep productivity requires not only effective actions on its various components (Yakubu and Musa-Azara, 2013), but also may rely on the body morphometric traits of animals. Few studies are carried on the characterization of Djallonke sheep reared in Benin studies (Gbangboché et al., 2004; Akouedegni et al., 2013; Awohouedji et al., 2013), and no published data exist on the body size of the different ecotypes of reared Djallonke sheep in Benin. The aim of the current survey is to investigate deeply on the body morphometric traits of West African Dwarf sheep of Djallonke breed in relation with the ecotype (North and South), age and type of birth.

\section{Materials and Methods}

\section{Study Area}

The study was thus conducted conjointly at the North and the South of Benin respectively in the departments Atlantic and Borgou. Situated between the latitudes of $6^{\circ} 20^{\prime}$ and $12^{\circ} 30^{\prime}$ north and between the longitudes of $1^{\circ} 30^{\prime}$ and $3^{\circ} 45$ East, the republic of Benin covers an area of $113440 \mathrm{~km} 2$ with a population of 10448647 inhabitants (INSAE, 2015) and a density of60 hab./km2.

The department Atlantic exhibits climatic conditions of sub-equatorial type, characterized by two rainy seasons with an uneven spatial and temporal distribution of rainfall: major (from April to July) and minor (from September to November). These two seasons are separated by a dry season. Average rainfall is close to $1200 \mathrm{~mm}$ per year. The monthly average temperatures vary between 27 and $31^{\circ} \mathrm{C}$ and the relative air humidity fluctuates between $65 \%$, from January to March, and $97 \%$, from June to July. The department Borgou exhibits climatic conditions of Sudan type, characterized by only one rainy season (from April to October) and one dry season (November to March). Average rainfall varies between 900 and $1300 \mathrm{~mm}$ per year while the average annual temperature is $26^{\circ} \mathrm{C}$ with a maximum of $32^{\circ} \mathrm{C}$ in March and a minimum of $23^{\circ} \mathrm{C}$ from December to January. The relative humidity varies between 30 and $70 \%$. Vegetation of Borgou department is a diversified savannah where tree density decreases towards the North.

\section{Data Collection}

The study was carried to investigate the morphometric parameters of dwarf sheep of Djallonke breed according to the ecotype, age and the type of lambing (litter size). Data were collected from November 2013 to December 2015 on a total of 1061 dwarf sheep of Djallonke breed including 462 of North ecotype and 599 of South ecotype. These animals were all raised in a traditional system. Feeding was mainly based on natural pasture. The animals were put on pasture at about 7.30 a.m. and returned to the barns in the afternoon. They were then fed ad libitum a supplementary diet consisting of crop residues according to the traditional system. 


\section{TOUGAN ET AL.}

The sheep were treated for ectoparasites, drenched once every three months and given other veterinary attention when the need appeared. The material used for data collection was composed of a morphometric data file for recording the morphometric parameters and electronic balances of $5 \mathrm{~kg}$ and $40 \mathrm{~kg}$ of capability and accuracy of $1 \mathrm{~g}$ and $20 \mathrm{~g}$ respectively. The morphometric traits measured were live weight, chest perimeter, height at withers (HW), scapulo-ischium length (SIL), head length (HL), shoulders width (SW), hip length (PL), tail length (TL) and cannon perimeter (CP). The height measurement $(\mathrm{cm})$ was done using a graduated measuring stick. The length, width and perimeter measurements $(\mathrm{cm})$ were recoded using a tape rule. Measurements were done in the morning before the animals were grazing. All measurements were carried out by the same person, in order to avoid inter-individual variations.

\section{Statistical Analysis}

Records of live weight, chest perimeter, height at withers, scapulo-ischium length, head length, shoulders width, hip length, tail length and cannon perimeter were analyzed by ecotype (North and
South), age and birth type using the software Statistical Analysis System (SAS, 2006). For the analysis of variance, the fixed effects of the ecotype, age and birth type. The F test was used to determine the significance of each effect in the model. Means were compared two by two by the Student's t test.

\section{Results}

Variability of Morphometric Parameters of Dwarf Sheep of Djallonke Breed according to the Ecotype

Apart from scapulo-ischium length (body length) which was not affected by the ecotype $(\mathrm{P}>0.05)$, all other morphometric measurements varied significantly according to the ecotype of sheep. Indeed, the north ecotype sheep were significantly heavier $(\mathrm{P}<0.001)$ than south ecotype sheep. Similarly, they had the greater wither's height $(\mathrm{P}<0.001)$ and presented higher values for head length, shoulders width, hip length, tail length and cannon perimeter than south ecotype sheep. In the same way, chest perimeter of north ecotype sheep was $59.64 \mathrm{~cm}$ to $57.9 \mathrm{~cm}$ for the sheep of South ecotype $(\mathrm{P}<0.05)$.

Table 1: Variability of morphometric parameters of dwarf sheep of Djallonke breed according to the ecotype.

\begin{tabular}{|c|c|c|c|c|c|}
\hline \multirow{2}{*}{ Variables } & \multicolumn{2}{|c|}{ North } & \multicolumn{2}{|r|}{ South } & \multirow{2}{*}{ ANOVA } \\
\hline & Mean & Standard error & Mean & Standard error & \\
\hline Live weigth & 14.14 & 0.44 & 12.70 & 0.42 & **** \\
\hline Head length & 15.44 & 0.28 & 14.93 & 0.26 & $* * *$ \\
\hline Body length & 50.70 & 0.96 & 52.25 & 0.90 & NS \\
\hline Shoulders width & 13.72 & 0.40 & 12.09 & 0.37 & $* * *$ \\
\hline Hip length & 17.43 & 0.34 & 14.37 & 0.31 & **** \\
\hline Tail length & 22.77 & 0.61 & 21.64 & 0.57 & $* * *$ \\
\hline Cannon perimeter & 6.67 & 0.35 & 6.08 & 0.33 & $* * *$ \\
\hline Wither's height & 48.34 & 0.81 & 45.79 & 0.76 & $* * *$ \\
\hline Chest perimeter & 59.64 & 3.25 & 57.91 & 3.05 & ** \\
\hline
\end{tabular}

ANOVA: Variance analysis, NS: $\mathrm{P}>0,05,{ }^{* *}: \mathrm{P}<0.01,{ }^{* * *}: \mathrm{P}<0.001$. 
Variability of Morphometric Parameters of Dwarf Sheep of Djallonke Breed according to the Age

The morphometric parameters were strongly affected by the age of sheep. The values of live weight, head length, scapulo-ischium length, hip length, tail length and height at wither increased very significantly with the age of animals $(\mathrm{P}<0.001)$. The shoulders width at 12 months $(14.82 \mathrm{~cm})$ was significantly higher than shoulders width at 1 month, 3 months and 6 months but similar to the value recorded at
9 months old $(13,98 \mathrm{~cm})$. By the same way, cannon perimeter at 1month and 3months are similar but lesser than those found at 6months, 9 months and 12 months which also presented similar values and ranging between $6.64 \mathrm{~cm}$ and $68.1 \mathrm{~cm}(\mathrm{P}<0.001)$. However cannon perimeter at 3 month $(5.94 \mathrm{~cm})$ and 12 months $(6.81 \mathrm{~cm})$ were similar. Furthermore, chest perimeter at 12 months was significantly higher than chest perimeter at 1month, 3 months and 6 months $(\mathrm{P}<0.001)$ but similar to chest perimeter at 9 months.

Table 2: Variability of morphometric parameters of dwarf sheep of Djallonke breed according to the age.

\begin{tabular}{|c|c|c|c|c|c|c|c|c|c|c|c|}
\hline \multirow[b]{2}{*}{ Variables } & \multicolumn{2}{|c|}{1 month } & \multicolumn{2}{|c|}{3 months } & \multicolumn{2}{|c|}{6 months } & \multicolumn{2}{|c|}{9 months } & \multicolumn{2}{|c|}{12 months } & \multirow[b]{2}{*}{ ANOVA } \\
\hline & Mean & $\begin{array}{c}\begin{array}{c}\text { Standard } \\
\text { error }\end{array} \\
\end{array}$ & Mean & $\begin{array}{c}\text { Standard } \\
\text { error }\end{array}$ & Mean & $\begin{array}{c}\text { Standard } \\
\text { error }\end{array}$ & Mean & $\begin{array}{c}\text { Standard } \\
\text { error }\end{array}$ & Mean & $\begin{array}{c}\text { Standard } \\
\text { error }\end{array}$ & \\
\hline Live weigth & $5.32 \mathrm{a}$ & 0.44 & $9.25 b$ & 0.43 & $13.66 \mathrm{c}$ & 0.43 & $17.40 \mathrm{~d}$ & 0.50 & $21.48 \mathrm{e}$ & 0.52 & $* * *$ \\
\hline Head length & $11.89 \mathrm{a}$ & 0.27 & $13.59 \mathrm{~b}$ & 0.27 & $15.72 \mathrm{c}$ & 0.27 & $16.91 d$ & 0.31 & $17.83 \mathrm{e}$ & 0.35 & *** \\
\hline Body length & $37.70 \mathrm{a}$ & 0.94 & $46.39 b$ & 0.93 & $54.03 c$ & 0.92 & $57.64 d$ & 1.07 & $61.59 \mathrm{e}$ & 1.22 & *** \\
\hline Shoulders width & $10.15 a$ & 0.39 & $11.88 \mathrm{~b}$ & 0.39 & $13.69 \mathrm{c}$ & 0.39 & $13.98 \mathrm{~cd}$ & 0.45 & $14.82 \mathrm{~d}$ & 0.51 & $* * *$ \\
\hline Hip length & $12.08 \mathrm{a}$ & 0.34 & $14.51 \mathrm{~b}$ & 0.33 & $15.63 c$ & 0.33 & $17.65 d$ & 0.38 & $19.62 \mathrm{e}$ & 0.44 & **** \\
\hline Tail length & $17.24 \mathrm{a}$ & 0.60 & $20.31 b$ & 0.59 & $22.48 \mathrm{c}$ & 0.59 & $24.65 d$ & 0.69 & $26.36 d$ & 0.79 & $* * *$ \\
\hline Cannon perimeter & $5.75 \mathrm{a}$ & 0.34 & $5.94 \mathrm{ab}$ & 0.34 & $6.64 c$ & 0.39 & $6.71 \mathrm{c}$ & 0.34 & $6.81 \mathrm{cb}$ & 0.45 & *** \\
\hline Wither's height & $37.82 \mathrm{a}$ & 0.79 & $43.48 b$ & 0.78 & $48.52 c$ & 0.78 & $51.57 \mathrm{~d}$ & 0.91 & $53.95 d$ & 1.03 & $* * *$ \\
\hline Chest perimeter & $42.00 \mathrm{a}$ & 3.21 & $51.90 \mathrm{~b}$ & 3.16 & $62.52 c$ & 3.15 & $65.97 \mathrm{~cd}$ & 3.67 & $71.49 \mathrm{~d}$ & 4.18 & **** \\
\hline
\end{tabular}

${ }^{* * *}: \mathrm{P}<0.001$. The means between the classes of the same line followed by different letters differ significantly at the threshold of $5 \%$.

\section{Variability of Morphometric Parameters of Dwarf Sheep of} Djallonke Breed according to the Type of Lambing (Litter Size)

The birth type affect the morphometric parameters of Djallonke sheep. The single born lamb weighed heavier than twin born lamb but presented similar weight to triple and quadruple born lambs. In the same way, scapulo-ischium length, shoulder or back width and wither's height of single born lambs were significantly higher $(\mathrm{P}<0.01)$ than twin born lambs but similar to triplet and quadruplet lambs. The hip of twin, triplet and quadruplet lambs are similar but less long than single lamb $(\mathrm{P}<0.001)$. However, tail length of triplet lambs $(24.22 \mathrm{~cm})$ was significantly higher than single, twin and quadruplet lamb which are similar and varied between $19.35 \mathrm{~cm}$ and $22.83 \mathrm{~cm}(\mathrm{P}<0.01)$. Nevertheless, the head length, cannon perimeter and height at wither didn't significantly vary according to the birth type $(\mathrm{P}>0.05)$.

J. Anim. Pro. Adv., 2016, 6(10): 999-1007 
TOUGAN ET AL.

Table 3: Variability of morphometric parameters of dwarf sheep of Djallonke breed according to the type of lambing (litter size).

\begin{tabular}{|c|c|c|c|c|c|c|c|c|c|}
\hline \multirow{3}{*}{ Variables } & \multicolumn{8}{|c|}{ Litter size at lambing } & \multirow{3}{*}{ ANOVA } \\
\hline & \multicolumn{2}{|c|}{1} & \multicolumn{2}{|r|}{2} & \multicolumn{2}{|c|}{3} & \multicolumn{2}{|c|}{4} & \\
\hline & Mean & $\begin{array}{c}\text { Standard } \\
\text { error }\end{array}$ & Mean & $\begin{array}{c}\begin{array}{c}\text { Standard } \\
\text { error }\end{array} \\
\end{array}$ & Mean & $\begin{array}{c}\text { Standard } \\
\text { error }\end{array}$ & Mean & $\begin{array}{c}\begin{array}{c}\text { Standard } \\
\text { error }\end{array} \\
\end{array}$ & \\
\hline Live weigth & $13.35 \mathrm{a}$ & 0.15 & $12.69 \mathrm{~b}$ & 0.15 & $12.80 \mathrm{ab}$ & 0.41 & $14.85 \mathrm{ab}$ & 1.59 & $* * * *$ \\
\hline Head length & $15.63 \mathrm{a}$ & 0.09 & $15.50 \mathrm{a}$ & 0.09 & $15.51 \mathrm{a}$ & 0.25 & $14.10 \mathrm{a}$ & 0.98 & NS \\
\hline Body length & $51.09 \mathrm{a}$ & 0.31 & $49.64 b$ & 0.33 & $50.29 \mathrm{ab}$ & 0.89 & $54.88 \mathrm{ab}$ & 3.39 & $* * *$ \\
\hline Shoulders width & $13.23 \mathrm{a}$ & 0.13 & $12.65 b$ & 0.14 & $12.94 \mathrm{ab}$ & 0.37 & $12.80 \mathrm{ab}$ & 0.14 & $* *$ \\
\hline Hip length & $16.33 \mathrm{a}$ & 0.11 & $15.91 b$ & 0.12 & $15.19 b$ & 0.32 & $16.17 \mathrm{ab}$ & 1.20 & $* * *$ \\
\hline Tail length & $22.83 \mathrm{ab}$ & 0.20 & $22.44 b$ & 0.21 & $24.22 \mathrm{a}$ & 0.57 & $19.35 \mathrm{ab}$ & 2.17 & $* *$ \\
\hline Cannon perimeter & $6.64 a$ & 0.11 & $6.33 \mathrm{a}$ & 0.12 & $6.30 \mathrm{a}$ & 0.32 & $6.21 \mathrm{a}$ & 1.23 & NS \\
\hline Wither's height & $48.21 \mathrm{a}$ & 0.26 & $47.22 b$ & 0.28 & $47.67 \mathrm{ab}$ & 0.75 & $45.17 \mathrm{ab}$ & 2.86 & $* *$ \\
\hline Chest perimeter & $58.62 \mathrm{a}$ & 1.06 & $59.11 \mathrm{a}$ & 1.14 & $57.38 \mathrm{a}$ & 3.03 & $59.99 a$ & 11.55 & NS \\
\hline
\end{tabular}

NS : $\mathrm{P}>0,05,{ }^{* *}: \mathrm{P}<0.01,{ }^{* * *}: \mathrm{P}<0.001$. The means between the classes of the same line followed by different letters differ significantly at the threshold of $5 \%$.

Correlation between Live Weight and Morphometric Parameters of Dwarf Sheep of Djallonke Breed of North Ecotype

The correlations between live weight and morphometric parameters of dwarf sheep of Djallonke breed of North ecotype are presented in Table 4. In this table, apart from the cannon perimeter which is slightly and positively associated with live weight $(\mathrm{r}=0.12$; $\mathrm{P}<0.05)$, weakly and positively associated with head length $(\mathrm{r}=0.16$; $\mathrm{P}<0.01)$, the other measured morphometric parameters are strongly and positively associated with live weight $(0.30 \leq \mathrm{r} \leq 0.85 ; \mathrm{P}<0.001)$ and head length $(0.26 \leq \mathrm{r} \leq 0.81 ; \mathrm{P}<0.001)$. By the same way, height at wither of sheep of North ecotype is strongly and positively correlated with scapulo-ischium length, chest perimeter, shoulders width, hip length and tail length $(0.29 \leq \mathrm{r} \leq 0.81 ; \mathrm{P}<0.001)$. The cannon perimeter is weakly and positively associated with shoulders width $(\mathrm{r}=0.16 ; \mathrm{P}<0.01)$.

The scapulo-ischium length was strongly and positively associated with chest perimeter, shoulders width, hip length and tail length $(0.29 \leq \mathrm{r} \leq 0.69 ; \mathrm{P}<0.001)$. The chest perimeter was strongly and positively associated with shoulders width, hip length and tail length $(0.21 \leq \mathrm{r} \leq 0.28 ; \mathrm{P}<0.001)$. 
VARIABILITY OF BODY MORPHOMETRIC PARAMETERS OF ...

Table 4: Correlation between live weight and morphometric parameters of dwarf sheep of Djallonke breed of North ecotype.

\begin{tabular}{|c|c|c|c|c|c|c|c|c|c|}
\hline Variables & $\begin{array}{c}\text { Live } \\
\text { weigth }\end{array}$ & $\begin{array}{c}\text { Head } \\
\text { length }\end{array}$ & $\begin{array}{l}\text { Wither's } \\
\text { height }\end{array}$ & $\begin{array}{c}\text { Cannon } \\
\text { perimeter }\end{array}$ & $\begin{array}{l}\text { Body } \\
\text { length }\end{array}$ & $\begin{array}{c}\text { Chest } \\
\text { perimeter }\end{array}$ & $\begin{array}{c}\text { Shoulders } \\
\text { width }\end{array}$ & $\begin{array}{c}\text { Hip } \\
\text { length }\end{array}$ & $\begin{array}{c}\text { Tail } \\
\text { length }\end{array}$ \\
\hline Live weigth & 1 & & & & & & & & \\
\hline Head length & $0.83^{* * *}$ & 1 & & & & & & & \\
\hline Wither's height & $0.85^{* * *}$ & $0.81^{* * *}$ & 1 & & & & & & \\
\hline Cannon perimeter & $0.12^{*}$ & $0.16^{* *}$ & $0.11^{\mathrm{NS}}$ & 1 & & & & & \\
\hline Body length & $0.85^{* * *}$ & $0.73^{* * *}$ & $0.81^{* * *}$ & $0.09^{\mathrm{NS}}$ & 1 & & & & \\
\hline Chest perimeter & $0.30^{* * * *}$ & $0.26^{* * *}$ & $0.29^{* * *}$ & $0.01^{\mathrm{NS}}$ & $0.29^{* * * *}$ & 1 & & & \\
\hline Shoulders width & $0.69^{* * *}$ & $0.76^{* * *}$ & $0.74^{* * *}$ & $0.16^{* *}$ & $0.69^{* * *}$ & $0.21^{* * *}$ & 1 & & \\
\hline Hip length & $0.76^{* * *}$ & $0.54^{* * *}$ & $0.64^{* * *}$ & $-0.01^{\mathrm{NS}}$ & $0.65^{* * *}$ & $0.27^{* * *}$ & $0.36^{* * *}$ & 1 & \\
\hline Tail length & $0.80^{* * *}$ & $0.63^{* * *}$ & $0.69^{* * *}$ & $0.05^{\mathrm{NS}}$ & $0.66^{* * *}$ & $0.28^{* * *}$ & $0.51^{* * *}$ & $0.71^{* * *}$ & 1 \\
\hline
\end{tabular}

NS : $\mathrm{P}>0,05{ }^{*}: \mathrm{P}<0.05{ }^{* *}: \mathrm{P}<0.01{ }^{* * *}: \mathrm{P}<0.001$. The means between the classes of the same line followed by different letters differ significantly at the threshold of $5 \%$.

\section{Correlation between Live Weight and Morphometric} Parameters of Dwarf Sheep of Djallonke Breed of South Ecotype The correlations between live weight and morphometric parameters of dwarf sheep of Djallonke breed of South ecotype are given in Table 5. It comes out from this table that apart from live weight which is weakly and positively associated with head length $(\mathrm{r}=0.82 ; \mathrm{P}<0.01)$ and height at wither which doesn't present any correlation with cannon perimeter $(\mathrm{P}>0.05)$, the all morphometric parameters were strongly and positively correlated $(\mathrm{P}<0.001)$ between them with coefficient of correlation varying from 0.30 to 0.86 (live weight); from 0.25 to 0.76 (head length); from 0.49 to 0.82 (height at wither); from 0.12 to 0.39 (cannon perimeter); from 0.46 to 0.87 (scapulo-ischium length); from 0.53 to 0.75 (chest perimeter); $r=0.35$ and 0.56 (shoulders width), $\mathrm{r}=0.63$ (hip length). 


\section{TOUGAN ET AL.}

Table 5: Correlation between live weight and morphometric parameters of dwarf sheep of Djallonke breed of South ecotype.

\begin{tabular}{|c|c|c|c|c|c|c|c|c|c|}
\hline Variables & $\begin{array}{c}\text { Live } \\
\text { weigth }\end{array}$ & $\begin{array}{c}\text { Head } \\
\text { length }\end{array}$ & $\begin{array}{c}\text { Wither's } \\
\text { height }\end{array}$ & $\begin{array}{c}\text { Cannon } \\
\text { perimeter }\end{array}$ & $\begin{array}{l}\text { Body } \\
\text { length }\end{array}$ & $\begin{array}{c}\text { Chest } \\
\text { perimeter }\end{array}$ & $\begin{array}{c}\text { Shoulders } \\
\text { width }\end{array}$ & $\begin{array}{c}\text { Hip } \\
\text { length }\end{array}$ & $\begin{array}{c}\text { Tail } \\
\text { length }\end{array}$ \\
\hline Live weigth & 1 & & & & & & & & \\
\hline Head length & $0.82^{* *}$ & 1 & & & & & & & \\
\hline Wither's height & $0.79^{* * *}$ & $0.72^{* * *}$ & 1 & & & & & & \\
\hline Cannon perimeter & $0.30^{* * * *}$ & $0.25^{* * *}$ & $0.05 \mathrm{NS}$ & 1 & & & & & \\
\hline Body length & $0.85^{* * * *}$ & $0.76^{* * *}$ & $0.77^{* * *}$ & $0.34^{* * *}$ & 1 & & & & \\
\hline Chest perimeter & $0.86^{* * *}$ & $0.75^{* * *}$ & $0.82^{* * * *}$ & $0.12^{* * *}$ & $0.87^{* * * *}$ & 1 & & & \\
\hline Shoulders width & $0.57^{* * * *}$ & $0.43^{* * *}$ & $0.49^{* * *}$ & $0.24^{* * *}$ & $0.46^{* * * *}$ & $0.53^{* * *}$ & 1 & & \\
\hline Hip length & $0.83^{* * *}$ & $0.69^{* * *}$ & $0.70^{* * *}$ & $0.39^{* * * *}$ & $0.78^{* * *}$ & $0.75^{* * *}$ & $0.56^{* * *}$ & 1 & \\
\hline Tail length & $0.64^{* * *}$ & $0.58^{* * *}$ & $0.68^{* * * *}$ & $0.20^{* * *}$ & $0.64^{* * * *}$ & $0.62^{* * * *}$ & $0.35^{* * *}$ & $0.63^{* * *}$ & 1 \\
\hline
\end{tabular}

\section{Discussion}

Variability of Morphometric Parameters of Dwarf Sheep of Djallonke Breed according to the Ecotype

The morphometric measurements varied according to the ecotype with the highest values of all measured parameters found in sheep of North ecotype. This result is in accordance with the report of Salako and Ngere (2002) where tail length was obtained to be the most discriminating variable between sheep of Yankasa breed and West African Dwarf sheep. Similar result was also reported by Traore et al., (2008) between the Sahelian and Sudan- Sahelian (Mossi) sheep of Burkina-Faso where Sahelian sheep had longer tail than Mossi sheep. According to FAO (2005), the characterization of body measurements of the Djallonke sheep presents great variability according to the latitudes and mediums of breeding.

Variability of Morphometric Parameters of Dwarf Sheep of Djallonke Breed according to the Age

Generally, all morphometric parameters of dwarf sheep of Djallonke measured increased progressively as sheep increases in age $(\mathrm{P}<0.001)$. This result is corroborate with the study of Otoikhian et al., (2008) on body measurement parameters of Ouda sheep. In the same way, according to Fajemilehin and Salako (2008), age strongly influenced body weight and body linear traits in West African Dwarf (WAD) goat. It also important to specify that, this scenario is however not surprising since the size and shape of the animal is expected to increase as the animal is growing with age.

Variability of Morphometric Parameters of Dwarf Sheep of Djallonke Breed according to the Type of Lambing (Litter Size)

In our study, the lambs of single birth were heavier with higher height than those of sheep from twin, triple and quadruple litters. Several authors reported similar results on effect of birth type on morphometric characteristics of Djallonke sheep with a superiority of values of single born lambs over twin and triplets (Gbangboche et al., 2006; Deribe and Taye, 2013).

These results could be due to the absence of food competition and intra-uterine space in single born lambs contrary to multiples born where there is competition (Zhang et al., 2008; Deribe and Taye, 2013). Furthermore, this could be caused by the poor milk production of the local ewe (Gbangboche et al., 2005a). A similar effect of birth type has been well documented for dwarf sheep (Yapi-Gnaoré et al., 1997; Gbangboche et al., 2005a, Mandal and al., 2010) and wall sheep (Ebangi et al., 2001).

Hary and Schwartz (2002) and Portolano et al., (2002) also reported that the single-born kids were found to be significantly heavier at all ages than twin-born kids and the variation in birth weight was associated to the type of birth, single birth was heavier than multiple born kids. However, the head length, cannon perimeter and height at wither didn't significantly vary according to the birth type. 
Correlation between Live Weight and Morphometric Parameters of Dwarf Sheep of Djallonke Breed of Benin

Several significant and positive correlations between body weight and different body measurements were established in the current study. Therefore, it is possible to predict live weigth in Djallonke sheeps of North and South ecotypes of Benin from their body size. Okpeku et al., (2011) reported similar correlations for the prediction of live weight by body measurements in sheep of Ghana. The results of this study corroborate those are earlier reported by research of Olatunji-Akioye and Adeyemo (2009) and Birteeb and Ozoje (2012) in which the chest perimeter proved to be the most significant variable for the prediction of body weight. Badi et al., (2002) and Leng et al., (2010) recommended the use of chest perimeter as most reliable variable to estimate body weight under field conditions were weighing bridges or scales are unavailable. The importance of chest perimeter in weight estimation could be as a result of the muscle and a little of fat along with bone structure which contribute to its formation (Yakubu, 2010). According to Birteeb and Ozoje (2012), the combination of chest perimeter and body length ensured a better estimation of live weight. This implies that body length assumes importance in weight prediction when used alongside chest perimeter. The two dimensional traits (chest circumference and body length) could symbolize body volume of an animal and so are indispensable in weight prediction in West African Dwarf goats. This same author report also that estimation of live weight can be more accurate when chest perimeter is combined with one or two other measurements.

\section{Conclusion}

The body morphometric traits of Djallonke sheep of Benin varied according to the ecotype with the highest values of all measured parameters found in sheep of North ecotype. Moreover, all morphometric parameters of dwarf sheep of Djallonke measured increased progressively as animal age increases. The lambs born from single litter were heavier with higher height than those of sheep from multiple litter size (twin, triple and quadruple litters). Significant and positive correlations exist between body weight and different body measurements. Therefore, selection based on one trait will improve the other traits as a correlated response since positive phenotypic correlations is reported to translate into positive genetic correlations.

\section{Acknowledgements}

The authors are grateful to the ministry of the higher education and scientific research of Benin.

\section{References}

Badi AMI, Fissehaye N, Rattan PJS (2002). Estimation of live body weight in Eritrean goat from heart girth and height at withers. Indian J. Anim. Sci., 72: 893-895.

Birteeb PT, Peters SO, Yakubu A, Adeleke MA, Ozoje MO (2012). Multivariate characterisation of the phenotypic traits of Djallonke and Sahel sheep in Northern Ghana. Tropic. Anim. Health Prod., 45: 267-274.

Deribe B, Taye M (2013). Evaluation of growth performance of abergele goats under traditional management systems in sekota district, Ethiopia. Pak. J. Biol. Sci., 16: 692-696.

Ebangi AL, Njoya A, Ngo-Tama AC, Awa DN, Mbah DA (2001). Genetic and phenotypic parameters of birth weight traits in Fulbe sheep in Cameroon. Revue. Elev. Méd. Vét. Pays Trop., 24(2): 147-151.

Fajemilehin OKS, Salako AE (2008). Body measurement characteristics of the West African Dwarf (WAD) goat in deciduous forest zone of southwestern Nigeria. Afr. J. Biotechnol., 7: 2521-2526.

FAO (2005). Global Livestock Production and Health Atlas. Food and Agriculture Organisation, Rome. http://www.fao.org/ag/aga/glipha/index.jsp (accessed March, 2005).

Gbangboche AB, Adamou-Ndiaye M, Youssao AKI, Farnir F, Detilleux J, Abiola FA, Leroy PL (2006). Non-genetic factors affecting the reproduction performance, lamb growth and productivity indices of Djallonke sheep. Small Rumin. Res., 64: 133-142.

Gbangboche AB, Hornich JL, Adamou-N'diaye M, Edorh AP, Fanir F, Abiola et Leroy PL (2005b). Caractérisation et maîtrise des paramètres de la reproduction et de la croissance des ovins Djallonké (Ovis Amon Aries). Ann. Méd. Vét., 149: 170-182.

Hary I, Schwartz HJ (2002). Effects of seasonal breeding on productive performance of pastoral goat herds in northern Kenya: a longitudinal analysis of growth in kids and body weight development of does. J. Arid Environ., 50: 641664.

INSAE (2005). Fichiers des villages et quartiers de villes, Département de l'Atlantique, novembre (2005), Cotonou, République du Bénin. p. 35. 


\section{TOUGAN ET AL.}

Leng J, Zhu R, Zhao G, Yang Q, Mao H (2010). Quantitative and qualitative body traits of longling yellow goats in China. Agric. Sci. China., 9: 408-415.

Mandal A, Dass G, Rout PK, Roy R (2010). Genetic parameters for direct and maternal effects on post-weaning body measurements of Muzaffarnagari sheep in India. Trop. Anim. Health. Prod., 109752-9756.

Okpeku M, Yakubu A, Peters SO, Ozoje MO, Ikeobi CON, Adebambo OA, Imumorin IG (2011). Application of multivariate principal component analysis to morphological characterization of indigenous goats in Southern Nigeria. Acta Agric. Slov., 98: 101-109.

Olatunji-Akioye AO, Adeyemo OK (2009). Liveweight and chest girth correlation in commercial sheep and goat herds in southwestern Nigeria. Int. Morphol J., 27: 49-52.

Otoikhian CSO, Otoikhian AM, Akporhuarho OP, Isidahoman C (2008). Correlation of body weight and some body measurement parameters in Quda sheep under extensive management system. Afr. J. Gen. Agri., 4(3): 129-133.

Portolano B, Todaro C, Finocchiaro R (2002). Estimation of the genetic and phenotypic variance of several growth traits of the Sicilian Girgentana goat. Small Ruminant Res., 45: 247-253.

Salako AE, Ngere LO (2002). Application of multifactorial structural discriminant analysis in the morphometric structural differentiation of West African Dwarf and Yankassa sheep in South West Nigeria. Niger. J. Anim. Prod., 29(2): 163-167.

Traoré A, Tamboura HH, Kaboré A, Royo LJ, Fernández I, Álvarez I, Sangaré M, Bouchel D, Poivey JP, Sawadogo L, Goyache F (2008). Multivariate analyses on morphological traits in Burkina Faso goat. Arch. Anim. Breed., 51: 588-600.

Yakubu A, Akinyemi MO (2010). An evaluation of sexual size dimorphism in Uda sheep using multifactorial discriminant analysis. Acta Agric. Scand., Sect A-Anim. Sci., 60: 74-78.

Yapi-Gnaoré CV, Oya A, Rege JEO, Dagnogo B (1997). Analysis of an open nucleus breeding programme for Djallonke sheep in the Ivoiry Coast. 1. Examination of non-genetics factors. Anim. Sci., 64: 291-300.

Zhang C, Yang L, Shen Z (2008). Variance components and genetic parameters for weight and size at birth in the Boer goat. Livest. Sci., 115: 73-79. 